\title{
A COMPARISON AND EVALUATION OF FOUR RECENT WORKS ON THE INTERPRETATION OF THE OLD TESTAMENT IN SOUTH AFRICA ${ }^{1}$
}

\author{
Christo JS Lombaard \\ Department of Old Testament \\ University of Pretoria
}

Abstract

In this article four recent books on Old Testament scholarship in South Africa are discussed. These four volumes are, in alphabetical order:

* Deist, F 1994: "Ervaring, rede en metode in Skrifuitleg. Wetenskapshistoriese ondersoek na Skrifuitleg in die Ned. Geref. Kerk” 1840-1990. Pretoria: Raad vir Geesteswetenskaplike Navorsing.

* Jonker, LC c. 1997: "Exclusivity and variety. Perspectives on multidimensional exegesis" (Biblical exegesis \& theology 19). Kampen: Kok Pharos Publishing House.

* Le Roux, JH 1993: “A story of two ways. Thirty years of Old Testament scholarship in South Africa” (Old Testament Essays Supplement Number 2). Pretoria: Verba Vitae.

* West, G 1991/1995²: "Biblical hermeneutics of liberation. Modes of reading the Bible in the South African context". Pietermaritzburg: Cluster Publications $/ 2^{\text {nd }}$ ed.: Pietermaritzburg: Cluster Publications \& Maryknol.

A brief summary of the substance of each of the four books is provided. The particular foci of each of the works are indicated, from which inferences are drawn about the contents of each, but also about what fell outside the scope of each. From these observations certain indications are given of what, to the author's mind, could be included in a historiographic work which would relate local Old Testament readings in a more representative way.

\section{Introduction}

The observation has perhaps by now become somewhat clichéd that South African exegesis of both the Old and New Testaments is characterised by a strong methodological awareness. Nevertheless, the remark remains true, perhaps even to the extent that the sentence above may be reformulated to read: "South African exegesis ... is characterised by too strong a methodological awareness". By this is meant that, one could surmise, more of the attention paid to exegetical methodology could have been paid to exegetical praxis.

This is not to say, of course, that the study of the Bible should not include investigation into the methods of scientific reading; it is indeed an important part of the discipline, and well established internationally (e.g. Kraus 1982; Barth 1984; Morgan \& Barton 1988; Goldingay 1995). Neither is it suggested above that

1. This article is a revised and updated version of a paper read at the 1998 Congress of the Old Testament Society of South Africa. 
exegesis is but a small tributary of - for our purposes here - Old Testament scholarship in South Africa; that is patently not the case. But perhaps most clearly demonstrated in the training of candidate ministers for the Afrikaans speaking churches in South Africa (and the bibliological sciences are indeed dominated locally by members of these churches - a situation which will remain unchanged until the English speaking churches require the classical languages of theology for ordination; cf. Lombaard 1997:27) ${ }^{2}$, but also by the at times seemingly obligatory introductory pages on exegetical methods in Old Testament dissertations (cf. e.g. Viviers 1990:1f; Human 1993:12f), exegesis in South Africa is first discussed, then praticed $^{3}$.

For this there are historical (see Le Roux 1993:16-27, 107-114) and, concurrently (see Deist 1994:31-365), underlying philosophical reasons. An added factor is, however, that the development of a home-grown exegetical method ${ }^{4}$ required of its proponents that the method be taught in order to nurture what might be called the "Pretoria school" of structuralist exegesis". Whereas a "new methodology" need not necessarily lead to such forthright nurturing (e.g., the influential German Old Testament scholar Gerhard von Rad's students apparently experienced some difficulty as he never quite explained his method; they had to pick it up as they went along), the distinctive South African set of circumstances (see again Le Roux 1993:16-27, 107-114) resulted in such an approach.

This methodological awareness among South African Old Testament scholars has given cause to a wide range of articles and books being published locally on exegetical method, the most famous of which is perhaps Deist \& Burden's prizewinning textbook from 1980, An ABC of biblical exegesis / ' $n$ ABC van Bybeluitleg. The 1990 s saw the publication of four such major works ${ }^{6}$ by South African Old Testament scholars, which will be discussed in this article. These works share a

2. I was involved from 1996 to 1999 - at the Theological Education by Extension College (Southern Africa), based in Johannesburg - with the training of ministers for a range of churches commonly described as "main line English speaking churches" (see www.tee.co.za). In the case of both predegree and degree level training at this institution, exegetical methodology is touched upon, but more time is devoted to students doing exegesis (always in translation, though). Interestingly, it is historical-critical exegesis which is taught from the onset of the training, whereas in the Afrikaans speaking church tradition in which I was trained, such exegesis was only carefully introduced, and at times spoken against, in the undergraduate years, and only really presented from the fourth year of the six years' training programme. Cf. for further perspectives in this regard West 1991:33; Parratt: 1987:150; Pauw 1994:22; Oosthuizen 1968:163.

3. The present author cannot plead non culpa to this state of affairs: my first published article was on exegetical methodology (Lombaard 1996:106-113), and here I am at it again...

4. This was on the initial impetus of WS Vorster (1971:139-148) and JA Loader (1975:14-23 \& 1978:1-40; on the latter reference see, importantly, Loader 1994:399-400), but was most influentially practised by WS Prinsloo; cf. Le Roux 1993:27-33 \& Lombaard 1996:107.

5. This term, coined in Lombaard 1998:203, seeks to indicate that South African structuralist exegesis finds affinity, though with differences, with other schools of structuralism. These include, in alphabetical order: the Amsterdam school in the Netherlands, the Claremont school in the USA (see e.g. Knierim 1992), the French structuralist school (see e.g. Barthes 1971:23-33), and the Richter school in Germany (see e.g. Richter 1971). These approaches seem all to have appropriated as their most celebrated endorsements, from France, the famous Cours de linguistique générale of de Saussure; from Brittain, the 1984 work by Barton, Reading the Old Testament. Method in biblical study; and from North America, the 1985 work by Childs, Old Testament Theology in a canonical context.

6. Smaller works on exegesis was also published during this time. See e.g. the text book by Van Dyk 1987 and the articles included in the Special Edition of Old Tesament Essays, 7/4, 1994, particularly those published in Sections B and C of this volume. 
general approach of looking, in the first instance, at local exegetical praxis thus far. It seems that, as the 1990s saw us approaching the turn of the millennium, a need arose (also internationally: cf. e.g. Martens \& Hasel 1992; Smend 1989; McKane 1989) to look at the way Old Testament science has come. Each in its particular way, the four works discussed below seek to explore and understand some of the pathways South African Old Testament exegesis has followed.

\section{An overview of the four works}

A very brief overview of the contents of each of the four works concerned will now be given.

\subsection{Deist's 'Ervaring, rede en metode...'}

Published as part of the Methodology project of the South African Human Sciences Research Council, this publication was the most extensive in a series of project publications on the history of exegesis in the three Afrikaans speaking "sister churches" " . It covers a time span of one and a half centuries, ending in 1990, which is divided into four main periods (1858-1900, 1900-1935, 1935-1957, 1958-1990), through which the ebb and flow of exegetical practice in the Dutch Reformed Church is traced. Two distinctive attributes characterise Deist's book:

1. It is based, and quite openly so (see Deist 1994: vi-viii), on constructs from the philosophy of history, a long time interest of Deist's (his first substantial publication on this matter was probably Deist 1976), and more specifically on the work of Feyerabend (1975), Kuhn (1970) and - particularly - Laudan (1977). This manner of analysis lends "Ervaring, rede en metode..." great value in indicating historical, social, cultural, and philosophical components of reality which "pushed forward", as it were, certain "truths" as acceptable within the particular church and scientific community in any of the given periods.

2. The sources consulted for this work add to the depth of the insights conveyed by Deist. The usual scientific publications are enlisted, but are complemented by interviews with and the experience of colleagues. In addition, a range of sources which do not normally find reflection in academic writings on the Old Testament are included. These sources comprise publications such as Die Kerkbode - the official weekly newspaper of the Dutch Reformed Church, the letters column of which, for instance, finds ample reflection in Deist's research and Die Gereformeerde Vaandel and Het Zoeklicht, which are long defunct publications of sectional interest within Dutch Reformed circles. Because these non-academic journals tend to reflect 1) less reasoned expressions of 2) often heart felt opinion 3) by a wider range of contributors than academic theologians only, much can be gleaned from such writings. This added focus contributes greatly to the credibility of Deist's representation of thoughts in any particular era in the history covered, and of the unfolding understanding of the Bible within the Dutch Reformed Church.

Complemented by a copious Bibliography as well as some 54 Addenda, this book is indispensable (though not without its weaknesses - see Erasmus 1997:138140) for any attempt to fathom not only the history of exegesis within the Dutch

7. These three churches are the Nederduitse Gereformeerde Kerk, the Nederduitsch Hervormde Kerk van Afrika and the Gereformeerde Kerke in Suid-Afrika. 
Reformed Church, but to a great extent also in any attempt to form an understanding of this church over the decades, its developments, and current debates within it as well (e.g. the ever recurring Jonah-in-the-fish debate). Indeed, any church and/or scientific community across the oikoumene would do well to use this volume as a case study, which would have substantial comparative value. Even more so, for Old Tesament scholars and also for serving ministers (with Erasmus 1997:140), this work provides welcoming perspectives on the long history of, also, historical scholarship and the strong movements in opposition to such scholarship many Bible scholars still feel themselves personally touched by in various ways.

\subsection{Jonker's 'Exclusivity and variety...'}

This 1993 Stellenbosch dissertation of Jonker's, published in Kampen in 1997, stands in the tradition of the exegetical debate in South Africa since the early 1970s. Though no explicit research history into local exegetical methodology is given, it is clear that this work springs from the at times artificial choice between synchronical and diachronical exegesis in South Africa. Jonker seeks to elude this choice by suggesting an "and - and" approach, rather than an "either - or" choice (cf. also Jonker 1998:1-15). After recounting extant exegetical analyses of Judges 13, first classically historical-critical, then narrative, Jonker suggests in the final part of his book a "multidimensional and/or integrational methodology". In this manner Jonker seeks to advance an exegetical praxis in which exclusivist claims have no place. Put another way: like a good dominee, Jonker seeks to mediate between two perceived oppositions, in order to achieve some measure of reconciliation between them.

Jonker's terminology ("multidimensional and/or integrational methodology") entices one to conclude that he is proposing a combination of synchronic and diachronic methods of exegesis into one "grand methodology" (Lombaard 1998:200). A closer description of his undertaking, however, would in my view be to term his proposal an "interaction" between exegetical approaches. One possible way Jonker suggests this might be done is by way of a communication model he adapts for this purpose. As one reviewer indicated (Levin 1998:134), a practical example, perhaps again on Judges 13 - which would overcome lingering philosophical doubts (Lombaard 1988:200) about Jonker's proposed "interactional approach" - would have helped to illustrate the possible value of his communication model. Levin (1998:134) hinted that such an exercise would probably not be possible. The year 1998, perhaps responding to such appraisals, saw the publication of such an attempt on the book of Jonah (Jonker 1998:10-13), in which Jonker draws some contours in this regard.

\subsection{Le Roux's 'A story of two ways...'}

Initially intended as a biographical project of modest scope on an older generation of members of the Old Testament Society of South Africa Le Roux's “A story of two ways..." grew into something much larger: a narrative on the most influential contributors to the work of the Old Testament Society of South Africa over the three decades since its inception in 1957 (apart from some earlier figures and some later publications). Le Roux is, of course, well qualified to write such a research history: his first doctorate was in Church History (Le Roux 1976), his second in Old Testament theology (Le Roux 1981).

After a prologue and a chapter highlighting the major catalysts in exegetical 
trends locally (Vorster, Loader, Deist), the book's chapters follow the traditional divisions of Old Testament literature: the Pentateuch, the Prophets, the Psalms, and Wisdom literature. Animated by personal recollections and "inside jokes", the work is not uncontentious. It divides the scholars discussed into two groups: those favouring text-immanent exegesis, and those favouring historical-critical readings.

Of the four works discussed here, this one caused the greatest controversy ${ }^{8}$. In two articles by Loader (1994:391-413 \& 1995:240-250), in a response on one of these by Le Roux (1995:82-101), and in an article by Prinsloo (1996:21-33), the debate was waged ${ }^{9}$. Loader's well-written 1994 evaluation of Le Roux's book centres on problems of style, irrelevant detail, inaccurate characterisation (so too Loader 1995:240-250), omissions, and an oversimplification of the local exegetical debate. Prinsloo (1996: esp. 21-23) places his focus, as far as his views on "A story of two ways..." are concerned, on inconsistencies of approach, unneeded malevolence, and misrepresentation of the subject matter.

The debate between all three these protagonists will not be continued. Le Roux will not answer his colleague and friend of many years after Prinsloo's tragic death ${ }^{10}$. And with Loader having taken up the prestigious Old Testament chair in Vienna, one does not know whether his interests would include continuing with this South African debate11. That aside, Le Roux's " A story of two ways..." remains the most substantial overview of local Old Testament scholarship available; indeed a reference work (as Loader 1994:394 suggested). Its critics warn, though, that this work too must be read critically.

\subsection{West's 'Biblical Hermeneutics...'}

"Biblical Hermeneutics...", West's Sheffield dissertation, was published twice: in Pietermaritzburg in 1991, and for an international readership, in New York state in 1995. It draws on European philosophical hermeneutics as interpreted by liberation, black and feminist theologians from the Americas, as well as some local scholarship. These contributions from liberation, black and feminist theologies are presented in detailed discussions, one after the other, and related to the South African situation. The latter entails specifically local liberation theology, and more accurately as represented in the readings by AA Boesak and IJ Mosala of the Cain and Abel narrative in Genesis $4{ }^{12}$.

8. Deist's work discussed above might potentially have claimed this "place of honour". It however remained unreviewed until 1997, and in Deist's own words to me during August 1996, the book was "doodgeswyg" (killed by silence). To my mind the culpability for this may well be sought with the publisher, which marketed this book very poorly indeed. The latter was one of the concerns which led to the writing of this paper.

9. If I may be allowed in true "Le Rouxian style" (Loaderian terminology!) a personal intermezzo here: I vividly recall the anticipation of the debate at the Faculty of Theology, University of South Africa in 1994 between Loader and le Roux. The expected "rough and tumble" which we as students forecasted, never ensued; it turned out to be a very civil affair. However, from the tone of the articles published from these papers read there, the underlying tension may still be discerned.

10. A collection of Prinsloo's Psalm-studies was recently published: see Prinsloo 2000.

11. Others have however added to the debate. See e.g. Spangenberg 1999, especially pages 591, 601-606.

12. Something neither West nor his reviewers note, but which resonates quite clearly if one has grown up in more or less the same church tradition as Boesak, is that Boesak's hermeneutics is typical of main stream exegesis amongst ministers in the Dutch Reformed Churches of the 1970s and ' 80 s. In this respect, Deist's work discussed above may complement West's here in an 
A distinction between "reading the text", "reading behind the text" and "reading in front of the text" is well employed to illustrate what finds close equivalence to the conventional understanding of, respectively, a text immanent reading, a historicalcritical reading, and a reader response method. West's own approach corresponds to the latter: his interest is the way the Bible is read by others, specifically with a view to political liberation. In this approach West remains consistent, with his work progressively making the case that "ordinary readers" (which is his terminology for poor, marginalised, oppressed Bible readers; see the criticism by Conradie 1993:6265 of this exclusive criterion, though from personal correspondence I gather that West is open to other groups of readers as well) must be given due regard. In line with this progression, the book culminates in two chapters relating, respectively, practical experiences in, and a brief discussion of such "ordinary" readings. In addition, the work of the Institute for the Study of the Bible, attached to the School of Theology, University of Natal, Pietermaritzburg, is described, which is enriched by the two appendices included.

The book was generally well reviewed (e.g. Marais 1997:151-153; Bergant 1993: 189-190; Walker 1992:103-104), and has given rise to West continuing his work of investigating theologically untrained readers' interpretation of the Bible (West 1998:3-32; 1997a: 99-115). In this manner West is making a valuable contribution also to the way the scientific community of Old Testament readers perceive and understand their academically less trained co-readers of the Bible.

\section{Some evaluative remarks}

Following on the fleeting overviews above of the four authors' books, in the next two parts of this article will consider, first, what these four authors have in common, and then what has fallen outside the scope of their contributions. The latter will provide pointers to what could additionally be included, if one were to gain a more extensive overview of the way South Africans interpret the Old Testament.

\subsection{What these four works have in common}

All four the works discussed above primarily study students of the Old Testament, rather than the Old Testament itself. All four commit themselves in terms of a preferred exegetical approach, which is to be ascertained by evaluative remarks in the texts discussed (in addition to other published works): with Deist and Le Roux, quite openly, the historical-critical methods are embraced. Although their two younger counterparts camouflage their preferences with statements to the effect that none of the methods they discuss are preferred for the purposes of their respective works (Jonker 1997a: 269ff; West 1991:45), I would propose that were a choice to be extracted from them, they too would be historically inclined. Jonker's concern in Exclusivity and variety, though, is to promote a "fourth phase" (Jonker 1998:10) in exegetical history: the legitimacy of both the diachronic and the synchronic approaches (and not, as he in personal correspondence corrected my interpretation in Lombaard 1998:199-202, to propose operationally combining the two approaches). West (1991), on the other hand, is more interested in present-day readings of the Old Testament than in the exegetical methods employed. Reading 
between the lines, I initially gathered that he might not be averse to a Christianity without the Bible for the sake of a just dispensation for marginalised people (others too have expressed related perceptions orally); in personal correspondence he however corrected this faint impression: "A liberation paradigm (as distinct from a liberal paradigm) takes the Bible seriously".

All four the authors discussed are existentially involved in their work. For West, his study unequivocally serves the cause of the oppressed (see e.g. West 1991:185 ${ }^{7}$ ). Jonker studied within the milieu of the Dutch Reformed Church, which implies no escape from the methodological debate. In addition, he has actively partaken of the debate (see e.g. Conradie et al. 1995), and for this has landed in hot water in Cape church circles (which, on a light-hearted note, probably bodes well for a good academic career!). Deist, active over decades in the exegetical debates of the Dutch Reformed Church and the Old Testament Society of South Africa, understood the issues he wrote about from the inside. And Le Roux (cf. Le Roux 1995:86) has been participating in and writing on the labours of the South African Old Testament Society for roughly a quarter of a century. That each of these authors knows the intellectual twists and emotional turns of the matters they write about, is thus beyond doubt.

However, their works are not simply "gut reactions" to what they have experienced. All base their work on solid philosophical presuppositions. West and Deist spell these theoretical points of reference out clearly in the opening pages of their respective books. Le Roux's philosophical grounding is well known from his other publications. Jonker's theoretical views are expounded in the opening and closing chapters of his work; from this and other publications of his the philosophical undercurrents can be deduced.

\subsection{What falls outside the scope of these four works?}

Every one of our four authors teaches us something. Because each work is of necessity confined to the analysis of a part of a greater reality, there remains in each case room for expansion, either by themselves or by those who would follow in their footsteps. If the indications below of such possible expansions are taken up, and augmented, perhaps an even more extensive panorama of the ways in which the Old Testament is interpreted locally, may be presented.

Deist opened the way to understanding long term developments in exegesis and hermeneutics, as such aspects were informed by culturally influenced views of acceptable truths. His focus is on the Afrikaans speaking churches only. Although the resources may be scarcer, for a variety of reasons, similar studies on what are usually termed the main line English speaking churches may be undertaken, and with great expectations. The same could be done with the African Independent Churches, evangelicals, charismatics, Catholics, as well as with the Jewish community. Such a focus on views on the Bible within any church or church group would do much to promote self-understanding, which on its part will benefit, internally to each community, a more informed, mature spirituality, and, externally will foster ecumenical relations because of a more secure sense of identity, commonalities, and differences (cf. Lombaard 1999:32-35). If Deist's work could stimulate a trend towards such related research, it would indeed be to the benefit of the church(es).

Jonker indicated a way around past "Berlin walls" of exegetical methodology. 
Although the methodological separation was not at all times equally harsh among professional exegetes, and although it seems to me that second generation followers of the respective exegetical ways may have been more disconnected from alternative approaches than were their teachers, the impression remains, at least with many ministers trained in this era, that a single correct exegetical means must be adhered to. This "binary way" of only noughts and ones, of only right or wrong, fits well with the ideas of modernity; such Platonic truths were however never truly human. Whatever the difficulties an "interactional" model - still in its infancy - may bring, its intentions are noble and its dialogical basis humane. Developments of this model, parallels with it, and alternatives to it would most probably be well advised.

Le Roux took the initiative to write a research history, not with some unattainable sense of objectivity in mind, but to tell the story the way he saw it, and he characterised (his critics would say: caricaturised) accordingly. To my mind, perhaps this is the way to continue, not despite the ensuing controversy, but because of it. Perhaps, in the debate, new perspectives will be opened. Here too I would suggest broadening the scope (which I understand is already being done, with a similar project being undertaken on the local New Testament society). However, the boundaries may also be stretched wider as far as the study of the Old Testament is concerned. A good deal of writing was done on the Old Testament outside of the boundaries of the Old Testament Society of South Africa. To give two examples: the training of many ministers for the English speaking churches was undertaken outside the sphere of government sponsored university education. Though not always producing truly academic writing, the institutions attached to the Joint Board for the Diploma in Theology frequently wrote their own course material. Somebody like Brian Banwell contributed great volumes of written course material, and influenced large numbers of student who studies at institutions attached to the Joint Board for the Diploma in Theology in this manner ${ }^{13}$. A second example is the work done in Baptist training colleges, which are traditionally independent of any state support. Yet the Old Testament is studied and researched in such institutions ${ }^{14}$. These two examples indicate that there is more research history to be written, if we are to attain a comprehensive overview of the ways in which the Old Testament was/is studied in South Africa. In addition, as Spangenberg (1999:591-600) indicated, Le Roux's history may be expanded to include sections of the Old Testament less intensely studied by South Africans as well.

On his part, Gerald West has opened up new vistas on the way the Bible is read by theologically and at times entirely untrained readers. His work has proved to be influential locally and internationally. Here too extension of such studies should in my view be encouraged. We know too little about the way the Bible is read by "ordinary readers" such as women's Bible study groups in Cape Town, converts from Islam in Lenasia, state officials in Pretoria, rich business people in Johannesburg, municipal workers in Welkom, farm workers in the Kalahari, technikon students in Bloemfontein... Here too much remains to be researched in order to sketch more fully the way the Bible, and specifically the Old Testament is interpreted in South Africa.

13. Banwell published a limited number of scholarly articles. His sole such contribution within the field of Old Testament science, to my knowledge, is Banwell 1989: 73-74.

14. My thanks to Dr David Firth, who pointed such matters out to me. 


\section{Conclusion}

The decade of the 1990s saw the production of four major, though widely divergent, works on Old Testament interpretation in South Africa. Each of these works says much about the, of necessity, limited focus of its subject matter. There are good reasons, I would submit, to expand on these projects. Perhaps the most important of these reasons at this juncture in the educational history of our country, is to provide Old Testament scientists with a greater awareness of the range of issues involved, in order the better to address the needs of our times. Of course, "relevance" to our times is not everything (cf. Thiselton 1992). In our present time, though, where issues of survival are at stake, it should be higher on our agenda than usual. 


\section{BIBLIOGRAPHY}

Barth, H 1984. Exegese des Alten Testaments. Leitfaden der Methodik. NeukirchenVluyn: Neukirchener Verlag.

Barthes, R The struggle with the angel: textual analysis of Genesis 32:23-33, in Barthes, R et al. (eds) 1974. Structural analysis and biblical exegesis: interpretational essays. Pittsburg: Pickwick Press, 21-33.

Barton, J 1984. Reading the Old Testament. Method in biblical study. London: Darton Longman and Todd.

Bergant, D 1993. Gerald O West Biblical hermeneutics of liberation. Modes of reading the Bible in the South African context (Monograph Series 1; Pietermaritzburg: Cluster, 1991). Catholic Biblical Quarterly 55: 189-190.

Childs, BS 1985. Old Testament Theology in a canonical context. London: SCM Press.

Conradie, E et al. 1995. Fishing for Jona. Various approaches to biblical interpretation. Belville: University of the Western Cape Press. (Also available in Afrikaans under the title $O p$ soek na Jona. Verskillende benaderings tot die interpretasie van die Bybel.)

Conradie, E et al. 1995. Op soek na Jona. Verskillende benaderings tot die interpretasie van die Bybel. Belville: University of the Western Cape Press.

Conradie, E 1993. Review article: Biblical hermeneutics of liberation. Modes of reading the Bible in the South African context, by Gerald $O$ West (Pietermaritzburg: Cluster Publications, 1991). Journal of Theology for Southern Africa 85: 61-65.

Deist, FE 1976. Historiese heuristiek, teologiese hermeneutiek en Skrifgesag. Port Elizabeth: UPE.

Deist, FE \& Burden, JJ 1980. An ABC of biblical exegesis. Pretoria: J.L. van Schaik.

Deist, FE \& Burden, JJ 1980. ' $n$ ABC van Bybeluitleg. Pretoria: J.L. van Schaik.

Deist, F 1994. Ervaring, rede en metode in Skrifuitleg. 'n Wetenskapshistoriese ondersoek na Skrifuitleg in die Ned. Geref. Kerk 1840-1990. Pretoria: Raad vir Geesteswetenskaplike Navorsing.

Erasmus, F 1997. Boekbeskouing: Deist, Ferdinand Ervaring, rede en metode in Skrifuitleg. 'n Wetenskapshistoriese ondersoek na Skrifuitleg in die Ned. Geref. Kerk 1840-1990. 1994. Pretoria: RGN. Ned. Geref. Teologiese Tydskrif 1997, pp 138-140.

Feyerabend, P 1975. Against method. London: NLB.

Goldingay, J 1995. Models for interpretation of Scripture. Grand Rapids: William B. Eerdmans / Carlisle: Paternoster.

Human, DJ 1993. Die begrip 'berit' in 'n aantal klaagpsalms: 'n perspektief (ongepubliseerde DD-proefskrif). Pretoria: Universiteit van Pretoria.

Jonker, LC c. 1997a. Exclusivity and variety. Perspectives on multidimensional exegesis (Biblical exegesis \& theology 19). Kampen: Kok Pharos Publishing House.

Jonker, LC 1997b. Bridging the gap between Bible readers and the professional exegetes. Old Testament Essays 10/1 : 69-83.

Jonker, L 1998. Reading Jonah multidimensionally: a multidimensional reading strategy for biblical interpretation. Scriptura 64: 1-15. 
Kuhn, T 1970. The structure of scientific revolutions (2nd ed.). Chicago: University of Chicago Press.

Knierim, RP 1992. Text and concept in Leviticus 1:1-9. A case in exegetical method (Forschungen zum Alten Testament 2). Tübingen: J.C.B. Mohr (Paul Siebeck).

Kraus, H-J 1982. Geschichte der historisch-kritischen Erforschung des Alten Testaments (3., erw. Auflage). Neukirchen-Vluyn: Neukirchener Verlag.

Laudan, L 1977. Progress and its problems. Berkeley: University of California Press.

Le Roux, JH 1976. Die Paasbeskouing van Gaudentius van Brixa (ongepubliseerde DD-proefskrif). Pretoria: Universiteit van Suid-Afrika.

Le Roux, JH 1981. Uittog en Sinai: 'n uiteensetting en kritiese bespreking van Gerhard von Rad se beskouinge. (ongepubliseerde DTh-proefskrif). Pretoria: Unisa

Le Roux, JH 1993. A story of two ways. Thirty years of Old Testament scholarship in South Africa (Old Testament Essays Supplement Number 2). Pretoria: Verba Vitae.

Le Roux, JH 1995. Die kontoere van 'n weerwoord. Skrif en Kerk 16/1: 82-101.

Loader, JA 1975. Aspekte van menslike mag (ongepubliseerde DD proefskrif). Groningen: Universiteit van Groningen.

Loader, JA 1978: Gedagtes oor gekontroleerde eksegese. Hervormde Teologiese Studies 34/1: 1-40.

Loader, JA 1994: Die weg van die Here in die woestyn oftewel God se grootpad deur die wildernis: oor A Story of two ways. Skrif en Kerk 15/2: 392-413.

Loader, JA 1995: Adrianus van Selms: responsum. Journal for Semitics 7/2: 240-250.

Lombaard, CJS 1996. "n Nota op die aanwending van "tradisies" in die SuidAfrikaanse struktuuranalitiese eksegese van die Ou Testament. Skrif en Kerk 17/1: 106-113.

Lombaard, C 1997. Why the Pentateuch was written and why it will be studied in the new South Africa. A perspective from inter-culturality. The T.E.E. Journal 1/1: 23-33.

Lombaard, CJS 1998. Book review: Jonker, Louis C 1996. Exclusivity and variety. Perspectives on multidimensional exegesis. Kampen: Kok Pharos Publishing House. Old Testament Essays 11/1: 199-202.

Lombaard, CJS 1998. Book review: Sun, TC \& Eades, KL (eds) Problems in biblical theology. Essays in honor of Rolf Knierim. Grand Rapids: William B Eerdmans. Old Testament Essays 11/1: 202-206.

Lombaard, C 1999. The Bible and ecumenism, in Lombaard, C (ed.) Essays and exercises in ecumenism. Pietermaritzburg: Cluster Publications, 26-41.

Marais, SJ 1997. West, Gerald 1995. Biblical hermeneutics of liberation. Modes of reading the Bible in the South African context. 2nd rev ed. Pietermaritzburg: Cluster / Maryknoll, NY: Orbis. Old Testament Essays 10/1: 151-153.

Martens, EA \& Hasel GF (eds) 1992. The flowering of Old Testament Theology. A reader in twentieth century Old Testament Theology, 1930-1990. Winona Lake: Eisenbrauns.

McKane, W 1989. Selected Christian Hebraists. Cambridge: Cambridge University Press. Morgan, R \& Barton, J 1988. Biblical interpretation. Oxford: Oxford University Press. Old Tesament Essays (Special Edition) 7/4, 1994.

Oosthuizen, GC 1968. Post-Christianity in Africa. A theological and anthropological study. London: C. Hurst and Co.

Parratt, J 1987. Conclusion: Current issues in African theology, in Parratt. J (ed.) A 
reader in African Christian theology. London: SPCK.

Pauw, CM 1994. Theological education in Africa. Old Testament Essays (Special Edition) 7/4: 13-24.

Prinsloo, WS 1996. Eksegese is 'n spel (sonder reëls?). Acta Theologica 1996/2: 21-33.

Prinsloo, WS 2000. Die lof van my God so lank ek lewe. Pretoria: MedPharm Publikasies.

Richter, W 1971. Exegese als Literaturwissenschaft. Entwurf einer alttestamentliche Literaturtheorie und Methodologie. Göttingen: Vandenhoeck $\&$ Ruprecht.

Smend, R 1989. Deutsche Alttestamentler in drei Jahrhunderten. Göttingen: Vandenhoeck \& Ruprecht.

Spangenberg, IJJ 1999. Die Suid-Afrikaanse navorsingsgeskiedenis van die boek Daniël en die eksegetiese spel. Old Testament Essays 12/3: 591-608.

Thiselton, AC 1992. New horizons in hermeneutics. Grand Rapids: Zondervan Publishing House.

Van Dyk, PJ 1987. How to analyse the Bible. Discovering the context of Scripture by using the historical-critical method. Pretoria: J.L. van Schaik.

Viviers, $\mathrm{H}$ 1990. 'n Teksimmanente ondersoek na die samehang van die Ma ${ }^{c a}$ lôtpsalms (Pss. 120-134) (ongepubliseerde DD-proefskrif). Pretoria: Universiteit van Pretoria.

Vorster, WS 1971. Moderne linguistiek en Bybelnavorsing Theologia Evangelica IV/2: 139-148.

Walker, D 1992. Biblical hermeneutics of liberation. Modes of reading the Bible in the South African context. Gerald West. Pietermaritzburg: Cluster Publications. 1991. The South African Baptist Journal of Theology 1992: 103-104.

West, G 1991/19952. Biblical hermeneutics of liberation. Modes of reading the Bible in the South African context. Pietermaritzburg: Cluster Publications / $2^{\text {nd }}$ ed.: Pietermaritzburg: Cluster Publications \& Maryknoll: Orbis Books.

West, GO 1997. On the eve of an African Biblical Studies. Trajectories and trends. Journal of Theology for Southern Africa 99: 99-115.

West, GO 1998. Re-reading the Bible with African resources: interpretative strategies for reconstruction in a post-colonial, post-apartheid context on the eve of globalization. Journal of Constructive Theology 4/1: 3-32. 